\title{
Gastric ghrelin cell development is hampered and plasma ghrelin is reduced by delayed weaning in rats
}

\author{
Frida Fåk ${ }^{1}$, Lennart Friis-Hansen ${ }^{2}$, Björn Weström ${ }^{1}$ and Nils Wierup \\ Department of Experimental Medical Science, Division of Diabetes, Metabolism, and Endocrinology, Unit of Neuroendocrine Cell Biology and ${ }^{1}$ Department of \\ Cell and Organism Biology, Lund University, BMC B11, 22 184, Lund, Sweden \\ ${ }^{2}$ Department of Clinical Biochemistry, Rigshospitalet, University of Copenhagen, Copenhagen, Denmark \\ (Requests for offprints should be addressed to N Wierup; Email: nils.wierup@med.lu.se)
}

\begin{abstract}
The duration of breastfeeding has attracted much interest, as a prolonged period of breastfeeding has been shown to reduce the risk of developing obesity. The mechanism behind the reduced risk is, however, poorly understood. The novel hormone ghrelin augments appetite, promotes body weight increase and increases adiposity. The majority of circulating ghrelin emanates from endocrine cells in the oxyntic mucosa of the stomach. In newborn humans and rodents, the number of ghrelin cells is low after birth until weaning, when the cell population is greatly expanded. To date, information about the influence of weaning perturbations on ghrelin cell development is scarce. Therefore, we studied the effect of delayed weaning on gastric ghrelin expression and plasma ghrelin concentration. To this end, special food separator cages were used to prevent the pups from eating solid food, forcing them to drink milk up to 21 days of age. Gastric
\end{abstract}

ghrelin expression was examined by immunocytochemistry and in situ hybridisation, and plasma concentrations were assessed by RIA. Our data showed that gastric ghrelin expression and plasma ghrelin concentration are maintained at a lower level by delayed weaning. We also found that the relation between gastric ghrelin expression and body weight was altered by delayed weaning. Thus, control rats displayed a positive correlation between ghrelin expression and body weight, while no such correlation was evident in animals with delayed weaning. We conclude that delayed weaning exerts a negative influence on ghrelin expression, and that the onset of solid food intake may trigger normal ghrelin expression. Therefore, we suggest that ghrelin may constitute a hormonal link between the duration of breastfeeding and body weight development.

Journal of Endocrinology (2007) 192, 345-352

\section{Introduction}

Ghrelin is a 28 amino acid peptide originally isolated from rat stomach as an endogenous ligand for the growth hormone (GH) secretagogue receptor (GHS-R; Kojima et al. 1999). Ghrelin is mainly produced by endocrine cells in the oxyntic mucosa of the stomach, but ghrelin expression has been reported in a wide range of tissues including gastric antrum, intestine (Date et al. 2000, Dornonville de la Cour et al. 2001) and pancreas (Wierup et al. 2002, 2004); for a review see Korbonits et al. (2004). In addition to the somatotropic effects of ghrelin, the peptide stimulates food intake and increases adiposity (for review see Korbonits et al. (2004) and van der Lely et al. (2004)).

The regulation of appetite and food intake is highly complex and many hormonal as well as neuronal pathways participate (Druce \& Bloom 2006). Recent data suggest that important programming of satiety and hunger signalling occurs during the neonatal period, and that these settings may influence appetite and food intake later in life (Cripps et al. 2005). Interestingly, a role for ghrelin in these early settings has recently been argued (Grove \& Cowley 2005). The duration of breastfeeding has attracted much interest, as a prolonged period of breastfeeding has been shown to reduce the risk of developing obesity. The mechanism behind the reduced risk is, however, poorly understood (Kramer 1981, Harder et al. 2005, Gillman et al. 2006), for review see Arenz et al. (2004).

In the developing rat, gastric density of ghrelin cells is low until the weaning period when the ghrelin cell population is greatly expanded (Björkqvist et al. 2002, Hayashida et al. 2002, Wierup et al. 2004). Similar observations have been made in humans (Wierup et al. 2002). During the neonatal and pre-weaning period, the pancreas has been suggested to be an important source of circulating ghrelin, since islet ghrelin cells are numerous neonatally both in rodents and in humans (Wierup \& Sundler 2004, Wierup et al. 2004). Studies of the regulation of gastric ghrelin cell development have suggested that the ghrelin cell population is not affected by gastrin in the rat (Dornonville de la Cour et al. 2001), although gastrin null mutant mice as well as mice lacking both gastrin and cholecystokinin have affected ghrelin cell 
intramucosal topography, but normal density of ghrelin cells (Friis-Hansen et al. 2005). Even though it is clear that the gastric ghrelin cell population expands during the weaning period, there is, to our knowledge, no information on how ghrelin cell development is affected by weaning perturbations. Therefore, we studied the effect of delayed weaning on ghrelin cell development, ghrelin mRNA expression and plasma ghrelin concentrations.

\section{Materials and Methods}

\section{Animals}

Sprague-Dawley rats (Möllegaard Breeding and Research Ltd, Skensved, Denmark) were used. The rats were kept under standardised light conditions (a light period of $12 \mathrm{~h}$, from 0800 to $2000 \mathrm{~h}$ ) and at a constant temperature of $20 \pm$ $1{ }^{\circ} \mathrm{C}$ with a relative humidity of $50 \pm 10 \%$. Each dam was housed separately with its litter. The day of birth was assigned as day 0 , and within 3 days the litters were restricted to nine to thirteen pups per litter. The pups were kept with their mother and were fed with tap water and a pelleted rat chow ad libitum (Altromin, Breeding diet, B\&K Universal AB, Sweden, containing $22.5 \%$ protein, $5 \%$ fat, vitamins and minerals and the rest carbohydrates). The experiments were approved by the Animal Ethics Committees in Lund and Malmö.

\section{Design of delayed weaning experiments}

To study the effects of delayed weaning, three litters $(n=20$ in total) were prevented from eating solid food, from day 14 to day 21 , by placing the animals in specially designed cages with elevated cage lid, food pellets at a height of $17 \mathrm{~cm}$ above the cage floor (as compared with $8 \mathrm{~cm}$ in the control group). Thereby, the food was only available for the dam, while the pups were offered the dam's milk only. This group is hereinafter referred to as the delayed weaning (DW) group. Four control litters ( $n=32$ in total), kept with their mothers in standard cages, were given extra access to solid food by placing food pellets on the cage floor once daily from day 14 to day 21. On day 21, the pups were separated from their mothers for $3 \mathrm{~h}$ prior to killing. The pups were lightly sedated with $\mathrm{CO}_{2}$ and thereafter anaesthetised with a mixture of Ketamin (Ketalar, Park-Davis, Solna, Sweden, $0.5 \mathrm{mg} / \mathrm{g}$ body weight) and Azaperon (Stresnil, Janssen-Cilag Pharma, Vienna, Austria, $0.4 \mathrm{mg} / \mathrm{g}$ body weight) in $0.15 \mathrm{M} \mathrm{NaCl}$. On killing, the stomach content was checked and the food separator group had mainly clotted milk, while the control group had a mixture of milk and chow fragments.

\section{Tissue preparation}

For histochemical analysis, the stomach and pancreas were dissected, fixed overnight in Stefanini's solution (2\% paraformaldehyde and $0 \cdot 2 \%$ picric acid in $0 \cdot 1 \mathrm{M}$ PBS, $\mathrm{pH}$
$7 \cdot 2$ ), rinsed thoroughly in Tyrode solution containing $10 \%$ sucrose and frozen on dry ice. Sections (10 $\mu \mathrm{m}$ thickness) were cut and thaw-mounted on slides.

\section{Immunocytochemistry}

Antibodies were diluted in PBS ( $\mathrm{pH} 7 \cdot 2$ ) containing $0 \cdot 25 \%$ BSA and $0 \cdot 25 \%$ Triton X-100. Sections were incubated with primary antibodies (rabbit anti-ghrelin: code H-031-31, diluted at a ratio of 1:3200, Phoenix, Belmont, CA, USA; guinea pig anti-gastrin: code 8818, dilution of 1:1280, EuroDiagnostica, Malmö, Sweden; guinea pig anti-proinsulin: code 9003, diluted at a ratio of 1:2560, EuroDiagnostica) overnight at $4{ }^{\circ} \mathrm{C}$ in moisturising chambers. The sections were rinsed in PBS with Triton X-100 for $2 \times 10$ min. Thereafter, secondary antibodies with specificity for rabbit- or guinea pig$\operatorname{IgG}$, and coupled to either fluorescein isothiocyanate or TexasRed (Jackson, West Grove, PA, USA), were applied on the sections. Incubation was for $1 \mathrm{~h}$ at room temperature in moisturising chambers. The sections were again rinsed in PBS with Triton X-100 for $2 \times 10 \mathrm{~min}$ and then mounted in PBS:glycerol, 1:1. The specificity of immunostaining was tested using primary antisera pre-absorbed with homologous antigen $(100 \mu \mathrm{g}$ peptide/ $\mathrm{ml}$ antiserum at working dilution). Double immunofluorescence was also used, with combinations of primary antibodies (rabbit and guinea pig antibodies). The two primary antibodies were incubated simultaneously overnight at $4{ }^{\circ} \mathrm{C}$, followed by rinsing in PBS with Triton X-100 for $2 \times 10 \mathrm{~min}$. Thereafter, the two secondary antibodies were incubated simultaneously for $1 \mathrm{~h}$ at room temperature. In these studies, the controls included tests for inappropriate binding of the secondary antibodies.

\section{In situ hybridisation}

The ghrelin probe (Wierup et al. 2004) was complementary to the sequence 172-201 of rat ghrelin cDNA (GenBank accession number NM_021669; Kojima et al. 1999). BLAST search in the GeneBank database demonstrated lack of significant sequence similarity with any other mammalian cDNA. The probe was synthesised by DNA-technology A/S (Aarhus, Denmark) and was $3^{\prime}$-endtailed by $\left[\mathrm{S}^{35}\right] \mathrm{dATP}$ (Perkin-Elmer, Stockholm, Sweden; Mulder et al. 1993). The in situ hybridisation protocol has been described previously (Mulder et al. 1993). In brief, sections were rapidly air-dried, fixed in $4 \%$ paraformaldehyde for $15 \mathrm{~min}$, washed $2 \times 5 \mathrm{~min}$ in PBS and acetylated with $0.25 \%$ acetic anhydride in $0.1 \mathrm{M}$ triethanolamine for $10 \mathrm{~min}$. Thereafter, sections were dehydrated in graded ethanols, treated with chloroform for $5 \mathrm{~min}$, ethanol (95.5\%) for $5 \mathrm{~min}$ and again air-dried. Hybridisation was carried out in sealed moisturising chambers at $37^{\circ} \mathrm{C}$ overnight, using a probe concentration of approximately $1 \mathrm{pmol} / \mathrm{ml}$, followed by stringent posthybridisation washing $(1 \times$ SSC; $0.15 \mathrm{M} \mathrm{NaCl}, 0.015 \mathrm{M}$ sodium citrate). The slides were dipped in NTB 2 emulsion (Eastman Kodak Company, Rochester, NY, USA) and stored 
in light sealed boxes at $4{ }^{\circ} \mathrm{C}$ for 10-18 days. They were then developed in Kodak D-19, fixed in Kodak polymax and mounted on Kaiser's glycerol gelatine. As controls, sense probe or excess unlabelled probe was used, as described previously (Wierup et al. 2002).

\section{Imaging and cell quantification}

Immunofluorescence was examined in an epifluorescence microscope (Olympus, BX60, Tokyo, Japan). By changing filters, the location of the different secondary antibodies in double staining was determined. In situ hybridisation radiolabelling was examined in bright- or dark-field. Images were captured with a digital camera (Olympus, DP50). Ghrelin immunoreactive (IR) cells were counted in immunostained sections of gastric fundus, according to previously published protocols (Sundler et al. 1995), using a fluorescence microscope $(250 \times$ magnification; objective $25 \times$, eyepiece $10 \times$ and visual field $0.9 \mathrm{~mm}$ ). All ghrelin IR cells were counted in transverse sections (perpendicular to the mucosa surface) within 10-15 visual fields, covering the entire height and length of the mucosa (from rumen to antrum). This was repeated on three consecutive sections from each animal ( $n=17$ for each group). The oxyntic identity of the mucosa was always verified by the lack of gastrin immunoreactivity. Pancreatic ghrelin cell density was counted as reported previously (Wierup et al. 2004). To quantify labelling for ghrelin mRNA in the fundus, images were taken as above ( $n=8$ for each group). The density of in situ hybridisation labelling for ghrelin mRNA was calculated using Image Pro Plus software. Cells with labelling were delineated and the total cell area was calculated. Thereafter, the area of the silver grains within the delineated area was calculated. The density of labelling was expressed as labelled area per total cell area. At least 100 cells per animal were analysed. Oxyntic mucosa thickness was measured on transversely sectioned parts of the mucosa using Image Pro Plus software; at least 50 measurements were performed for each animal ( $n=10$ for each group).

\section{RIA for plasma ghrelin}

Blood samples were taken from the heart in anaesthetised animals and collected into ice-chilled tubes containing $1.5 \mathrm{mg}$ EDTA and 20000 IU aprotinin (Trasylol; Bayer, Leverkusen, Germany). Thereafter, the samples were centrifuged and plasma was collected and stored at $-80^{\circ} \mathrm{C}$ before further handling. The concentration of total ghrelin (acylated and non-acylated) was measured using a commercially available rat ghrelin RIA kit (RK-031-31, Phoenix, Belmont, CA, USA).

\section{Statistical analysis}

Results are shown as mean \pm S.E.M. Morphometric and plasma data were analysed using Student's unpaired $t$-test. Correlation analysis was performed using Spearman's test. Differences with a value of $P<0 \cdot 05$ were considered significant.

\section{Results}

\section{Stomach growth and immunocytochemistry for ghrelin}

In control rats, numerous ghrelin cells were seen from the base to the neck region of the glands in the oxyntic mucosa, as expected (Fig. 1A). However, in the DW group, the number of ghrelin cells in the oxyntic mucosa was markedly reduced
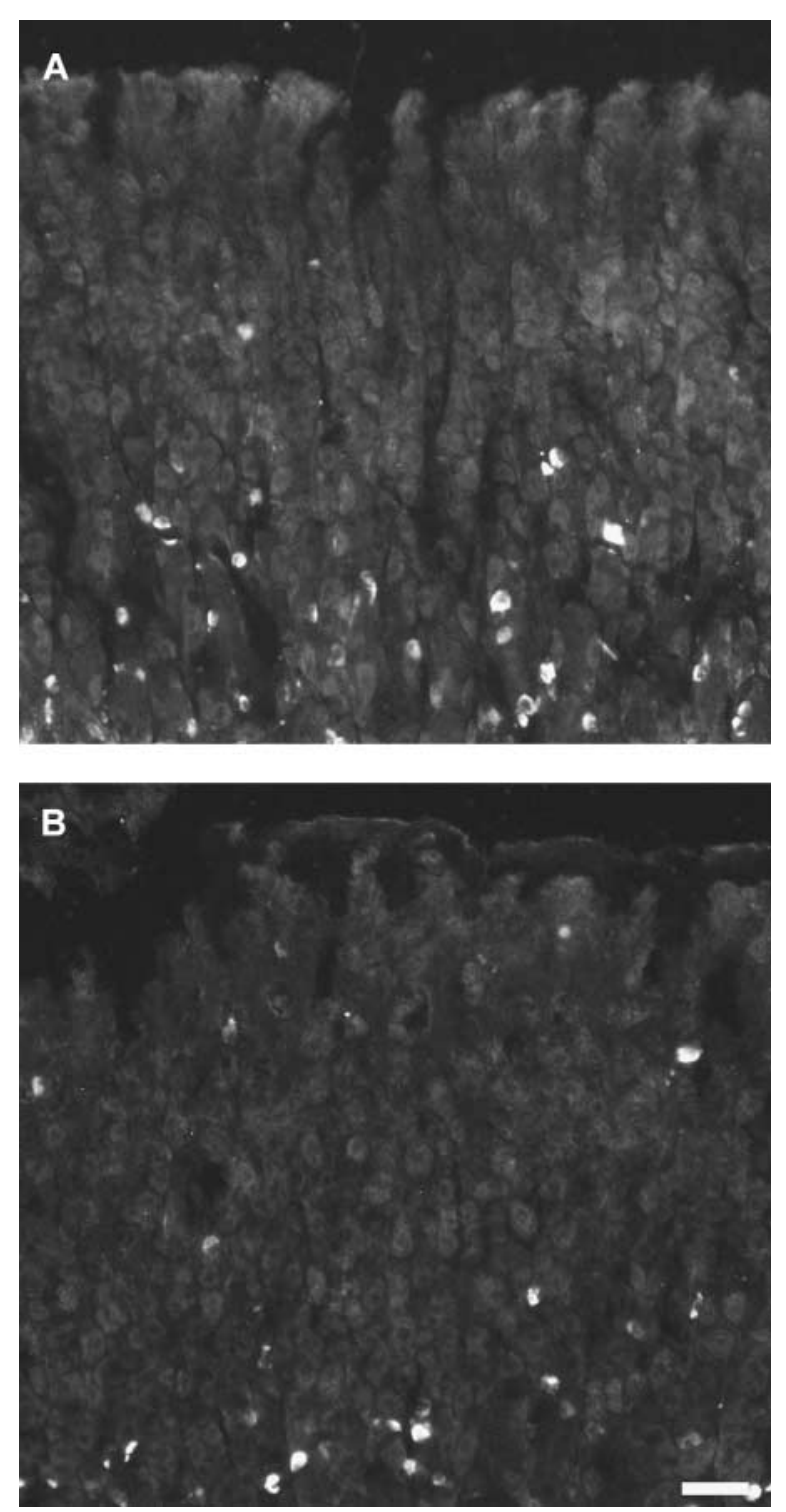

Figure 1 Fluorescence photomicrographs covering the entire height of the glands of rat oxyntic mucosa immunostained for ghrelin. At 21 days of age, rats with delayed weaning (B) kept in food separator cages display fewer ghrelin immunoreactive cells when compared with normally weaned control rats (A). Scale bar $=50 \mu \mathrm{m}$. 
(Fig. 1B). Morphometrical analysis of ghrelin cells per unit length of mucosa revealed that the DW rats had 30\% lower ghrelin cell density than the control rats (DW group: $24 \cdot 3 \pm$ $0 \cdot 7$ cells $/ \mathrm{mm}$ versus control group: $34 \cdot 0 \pm 1 \cdot 4$ cells $/ \mathrm{mm}$; $P<0.0001 ;$ Fig. 2A). There was no difference in stomach weight between the groups (DW group: $7 \cdot 5 \pm 0.5 \mathrm{~g}$ versus control group: $7 \cdot 6 \pm 0 \cdot 4 \mathrm{~g}$; NS; Fig. $2 \mathrm{~B}$ ), indicating that there was no general negative influence on stomach growth that could explain the observed difference in ghrelin cell density. Further, there was no difference in the thickness of the oxyntic mucosa between the groups (DW group: $430 \pm$ $17 \mu \mathrm{m}$ versus control group: $454 \pm 23 \mu \mathrm{m}$; NS; Fig. $2 \mathrm{C}$ ). On the other hand, the DW group had significantly lower body weight than the controls (DW group: $46 \cdot 3 \pm 1 \cdot 3 \mathrm{~g}$ versus control group: $56 \cdot 1 \pm 1 \cdot 1 \mathrm{~g} ; P<0 \cdot 0001$; Fig. $2 \mathrm{D})$. To test if the difference in ghrelin cell density between the two groups could be explained by the difference in body weight, ghrelin cell density was normalised to body weight. Although less pronounced, the DW group still displayed significantly lower ghrelin cell density than the control group (DW group: $0.53 \pm 0.036$ cells $/ \mathrm{mm}$ per $\mathrm{g}$ vs control group: $0.60 \pm$ 0.021 cells $/ \mathrm{mm}$ per g; $P=0.031$; Fig. $2 \mathrm{E})$. The reduced difference between the two groups that was seen after normalisation for body weight prompted analysis of the relationship between ghrelin cell density and body weight. Correlation analysis revealed that in the control group, the ghrelin cell density was positively correlated with the body weight $(r=0.61 ; P=0.0089 ;$ Fig. 3A). Interestingly, no such correlation was evident in the DW group $(r=-0 \cdot 14 ; P=$ $0 \cdot 61$; Fig. 3B). Quantification of pancreatic ghrelin cell density revealed that there was no difference in the islet ghrelin cell density between the two groups (DW group: $0 \cdot 26 \pm 0 \cdot 03$ cells/visual field versus control group $0 \cdot 22 \pm 0 \cdot 08$ cells/visual field; NS; Fig. 4).
In situ hybridisation for ghrelin $m R N A$

Cells with labelling for ghrelin were numerous in the oxyntic mucosa of control animals, as expected (Fig. 5A). In the DW group such cells were fewer (Fig. 5B) and morphometrical analysis revealed that ghrelin mRNA expression, measured as the labelling density per cell, was $60 \%$ lower in the DW group than in the control group $(P<0 \cdot 01$; Fig. $6 \mathrm{~A})$. No or only very weak background labelling was detected in control sections when using sense probe or excess of unlabelled probe (not shown).

\section{Plasma ghrelin}

The DW group displayed 20\% lower circulating concentrations of total ghrelin (des-acyl ghrelin and acylated ghrelin) than control animals (DW group: $140 \pm 9 \mathrm{pmol} / 1$ versus control group: $173 \pm 9 \mathrm{pmol} / \mathrm{l} ; P=0 \cdot 029$; Fig. $6 \mathrm{~B})$.

\section{Discussion}

The ghrelin cell density in both neonatal human and rat oxyntic mucosa is low when compared with the density in adults (Hayashida et al. 2002, Wierup et al. 2002, 2004). In rats, the ghrelin cell density remains low until the weaning period when it is greatly expanded, so that the density has reached adult levels at 20 days of age (Björkqvist et al. 2002, Hayashida et al. 2002, Wierup et al. 2004). Here, we show that delayed weaning, caused by preventing pups from eating solid food from day 14 to day 21, prevents the normal rise in both gastric ghrelin expression and plasma ghrelin concentration. Thus, fundic ghrelin cell density and ghrelin mRNA expression as well as circulating ghrelin concentration were
A

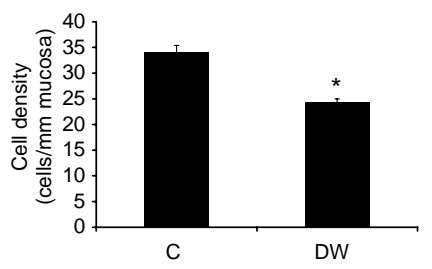

D

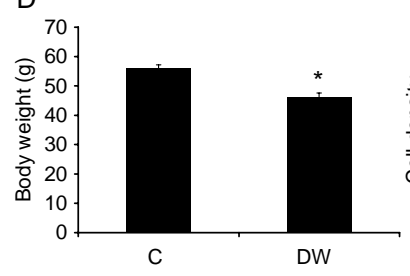

B

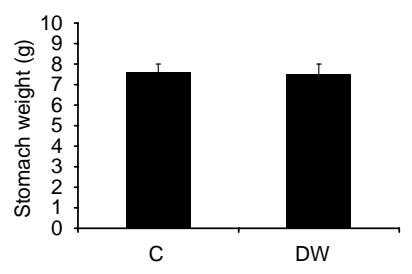

E

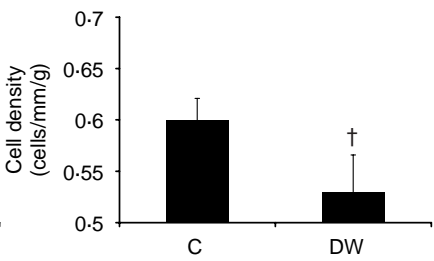

C

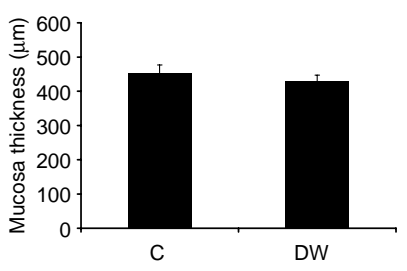

Figure 2 Morphometrical analysis revealed that the delayed weaning (DW) group has fewer ghrelin immmunoreactive cells/mm mucosa than control (C) rats (A). The stomachs of DW rats and controls have similar weight (B) and comparable thickness of the oxyntic mucosa (C). DW rats have lower body weight than control rats (D); this does, however, not explain the difference in ghrelin cell density (in A), since a difference remains when compensating for body weight (E). ${ }^{*} P<0 \cdot 0001,{ }^{+} P<0 \cdot 05$ DW versus $C$. 

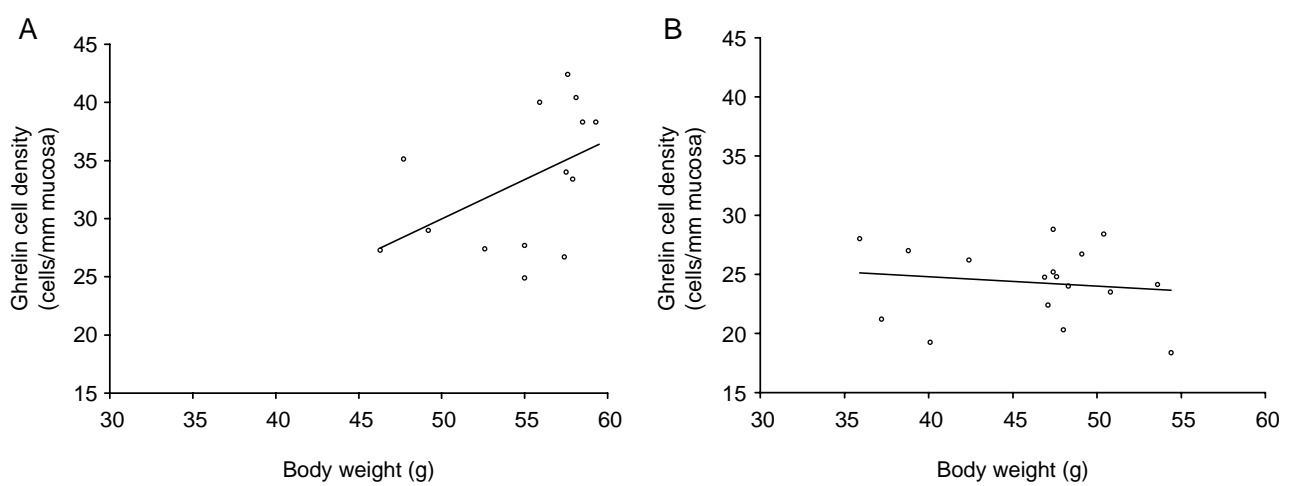

Figure 3 Normal control rats have a positive correlation between oxyntic mucosa ghrelin cell density and body weight $(\mathrm{A})(r=0 \cdot 61 ; P=0 \cdot 0089)$; no such correlation is seen in the delayed weaning group $(r=-0 \cdot 14 ; P=0 \cdot 61)$ (B).
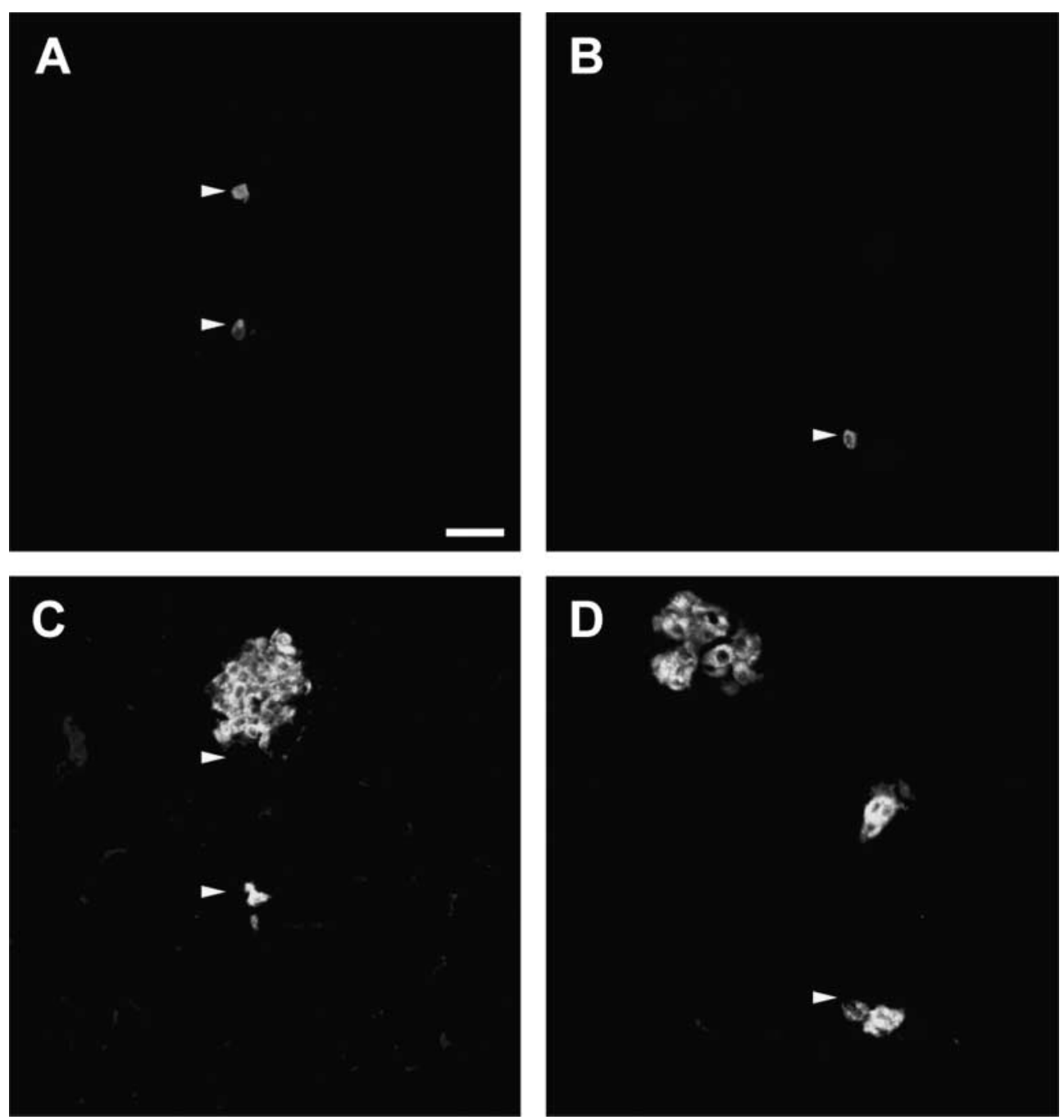

Figure 4 Fluorescence photomicrographs of rat pancreas double-immunostained for ghrelin (A and B) and insulin (C and D). A, C: delayed weaning. B, D: control. Delayed weaning does not affect the density of ghrelin cells in the pancreas. Location of ghrelin cells indicated by arrow heads. Scale bar $=50 \mu \mathrm{m}$. 

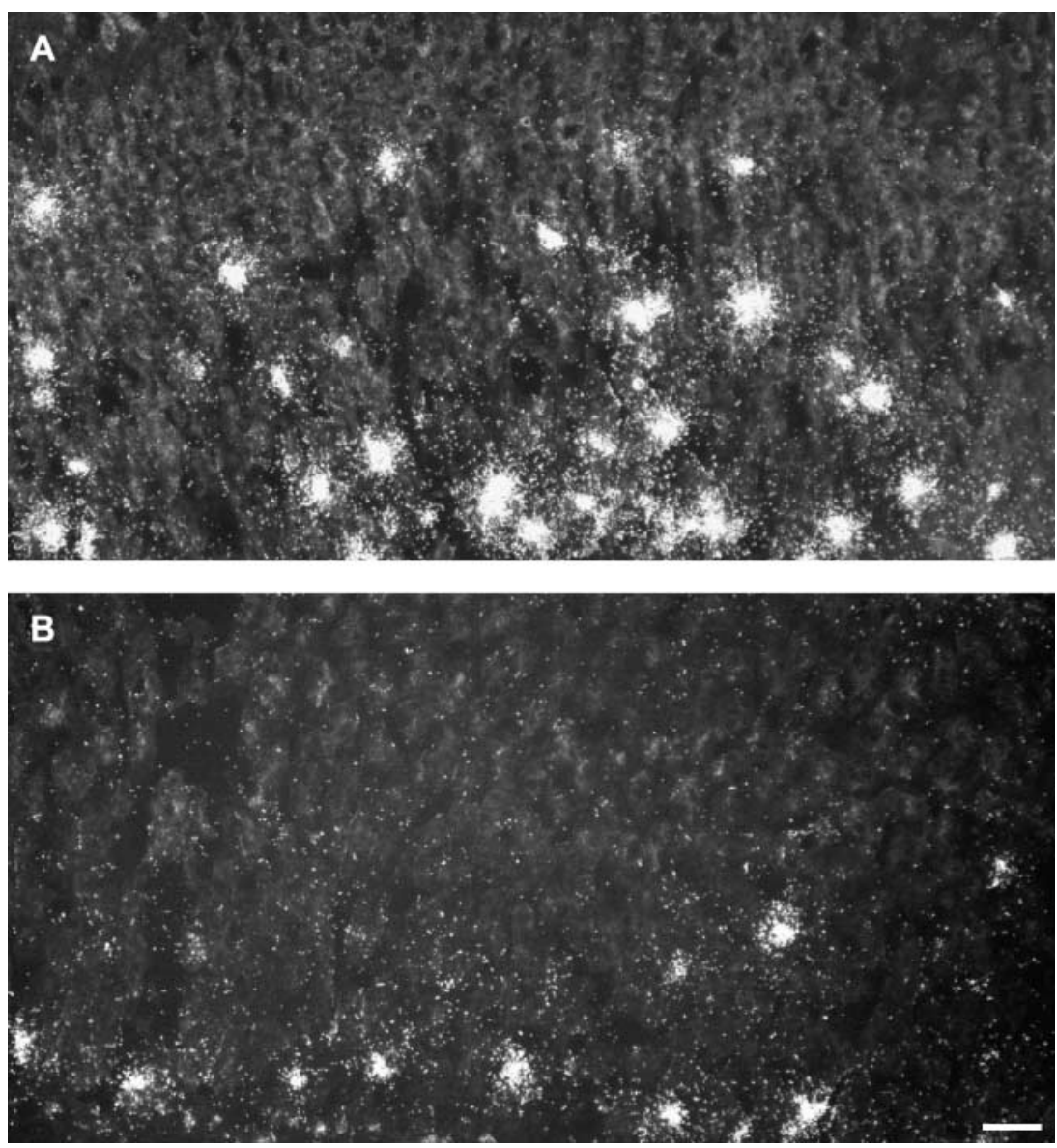

Figure 5 Rat oxyntic mucosa with in situ hybridisation labelling for ghrelin mRNA. Delayed weaning (DW) rats (B) display fewer cells with labelling for ghrelin than control rats (A). Note that the density of labelling per cell is weaker in the DW rats compared with the normal control rats. Scale bar $=50 \mu \mathrm{m}$.

significantly lower in the DW group when compared with the control group. The mechanism underlying our findings is not known, but could be related to the different nutrient composition of milk versus solid food. Rat milk contains high fat $(60 \%)$ and low carbohydrates $(<10 \%$; Girard et al. 1992) when compared with the solid food used here. Intake of high-fat diet has been associated with low plasma levels of a ghrelin (Beck et al. 2002). One possibility is therefore that the high fat content of the milk suppresses ghrelin. Another possibility is that ghrelin is present in rat milk, as reported for human milk (Aydin et al. 2006, Kierson et al. 2006), and acts to suppress the endogenous ghrelin expression. Further studies are warranted to elucidate these mechanisms. While this study was in progress, it was demonstrated that early weaned rats have higher concentrations of total ghrelin in the stomach (Nishi et al. 2005). Thus, weaning appears to be important for regulating gastric ghrelin expression, and ghrelin follows the pattern of other gut hormones (Björkqvist et al. 2002). In contrast, other processes involved in gastric maturation, for example proliferation of the gastric epithelium, are less dependent on nutrition, but instead more dependent on time (Gama \& Alvares 2000). In the present study, we also found that the ghrelin cell density in the oxyntic mucosa was positively correlated to body weight in the control group. The observed correlation indicates a relationship between ghrelin cell density and body weight development. In contrast, no such correlation could be detected in the DW group. The observed difference indicates that the onset of solid food intake may trigger ghrelin cell development and could be required for establishing the normal relationship between ghrelin and body weight. We also found that the DW rats had a lower body weight than the control group; these findings are in agreement with previous observations made in rats (Lee et al. 1982, Gama \& Alvares 2000) and humans (Kramer et al. 2004); for review see Rogers et al. (1997). The present finding of lower plasma concentration of ghrelin in the DW group is important and illustrates that the reductions in ghrelin cell density and ghrelin mRNA expression impact on systemic levels of ghrelin. 

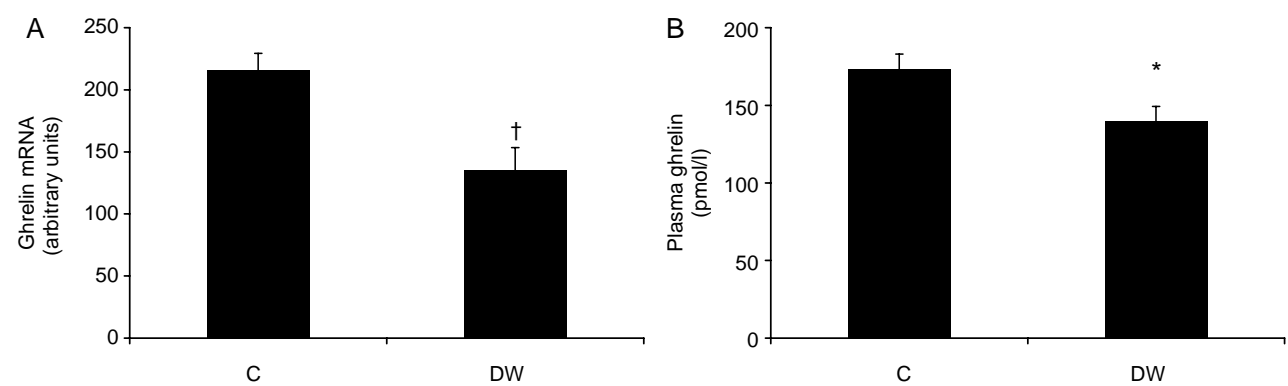

Figure 6 (A) Quantification of labelling density for ghrelin mRNA per cell. Delayed weaning (DW) rats display lower ghrelin mRNA expression per cell than control rats. DW rats have lower plasma concentration of total ghrelin when compared with control rats (B). ${ }^{*} P<0 \cdot 05,{ }^{\dagger} P<0 \cdot 01$ DW versus $\mathrm{C}$.

We previously reported that during the weaning period, when gastric ghrelin cell density was increasing, the density of ghrelin cells in the pancreatic islets decreased (Wierup et al. 2004). Since, in the present study, we observed a lower gastric ghrelin cell density in the DW rats, one could suspect that the normal decline in islet ghrelin cell density would be delayed. However, our present data showed that the islet ghrelin cell population was not affected by delayed weaning.

It is well documented that breastfeeding reduces the risk of the baby developing obesity, and it has also been argued that the duration of breastfeeding in humans may affect body weight later in life (Arenz et al. 2004). However, the mechanism behind this potentially protective effect is poorly understood. It was recently demonstrated that mice lacking ghrelin or GHS-R are resistant to diet-induced obesity when fed a high-fat diet during the early post-weaning period (Wortley et al. 2005, Zigman et al. 2005). In view of these findings, our present data showing decreased ghrelin expression and plasma ghrelin as a result of delayed weaning are intriguing. Although we have not examined body weight later than day 21, we suggest that ghrelin may represent a hormonal link between the duration of breastfeeding and body weight development later in life. Interestingly, Pinto et al. (2004) demonstrated that ghrelin is able to alter the ratio of excitatory to inhibitory synapses on hypothalamic pro-opiomelanocortin neurons. These neurons are indeed known to regulate satiety (for review see Harrold \& Williams 2006), and it is not inconceivable that synaptic alterations during their development may have a long-term impact on their excitability. Thus, it can be hypothesised that lower ghrelin levels, caused by delayed weaning, lead to alterations in synapses in appetite regulating neurons, which in turn may lead to altered long-term appetite settings.

In conclusion, this study demonstrates for the first time that delayed weaning maintains low gastric ghrelin expression and low plasma levels of ghrelin. In addition, the increase in plasma ghrelin and gastric ghrelin expression seen at weaning appear to be related to the onset of solid food intake and not merely to age.

\section{Acknowledgements}

This work was supported by grants from Swedish Medical Research Council (Project No. 4499), The Novo Nordisk, Tore Nilsson, Goljes Minne, The Swedish Society of Medicine and Ake Wiberg Foundations, and The Royal Physiographic Society. Technical assistance was given by Eva Hansson, Ann-Christin Lindh, Bo Lindberg and Doris Persson. The authors declare that there is no conflict of interest that would prejudice the impartiality of this scientific work.

\section{References}

Arenz S, Ruckerl R, Koletzko B \& von Kries R 2004 Breast-feeding and childhood obesity - a systematic review. International Journal of Obesity and Related Metabolic Disorders 28 1247-1256.

Aydin S, Aydin S, Ozkan Y \& Kumru S 2006 Ghrelin is present in human colostrum, transitional and mature milk. Peptides 27 878-882.

Beck B, Musse N \& Stricker-Krongrad A 2002 Ghrelin, macronutrient intake and dietary preferences in Long-Evans rats. Biochemical and Biophysical Research Communications 292 1031-1035.

Björkqvist M, Dornonville de la Cour C, Zhao CM, Gagnemo-Persson R, Håkanson R \& Norlen P 2002 Role of gastrin in the development of gastric mucosa, ECL cells and A-like cells in newborn and young rats. Regulatory Peptides 108 73-82.

Cripps RL, Martin-Gronert MS \& Ozanne SE 2005 Fetal and perinatal programming of appetite. Clinical Science 109 1-11.

Date Y, Kojima M, Hosoda H, Sawaguchi A, Mondal MS, Suganuma T, Matsukura S, Kangawa K \& Nakazato M 2000 Ghrelin, a novel growth hormone-releasing acylated peptide, is synthesized in a distinct endocrine cell type in the gastrointestinal tracts of rats and humans. Endocrinology 141 4255-4261.

Dornonville de la Cour C, Björkqvist M, Sandvik AK, Bakke I, Zhao CM, Chen D \& Håkanson R 2001 A-like cells in the rat stomach contain ghrelin and do not operate under gastrin control. Regulatory Peptides 99 141-150.

Druce M \& Bloom SR 2006 The regulation of appetite. Archives of Diseases in Childhood 91 183-187.

Friis-Hansen L, Wierup N, Rehfeld JF \& Sundler F 2005 Reduced ghrelin, islet amyloid polypeptide, and peptide YY expression in the stomach of gastrin-cholecystokinin knockout mice. Endocrinology 146 4464-4471.

Gama P \& Alvares EP 2000 Early weaning and prolonged nursing induce changes in cell proliferation in the gastric epithelium of developing rats. Journal of Nutrition 130 2594-2598. 
Gillman MW, Rifas-Shiman SL, Berkey CS, Frazier AL, Rockett HR, Camargo CA Jr, Field AE \& Colditz GA 2006 Breast-feeding and overweight in adolescence. Epidemiology 17 112-114.

Girard J, Ferre P, Pegorier JP \& Duee PH 1992 Adaptations of glucose and fatty acid metabolism during perinatal period and suckling-weaning transition. Physiological Reviews 72 507-562.

Grove KL \& Cowley MA 2005 Is ghrelin a signal for the development of metabolic systems? Journal of Clinical Investigation 115 3393-3397.

Harder T, Bergmann R, Kallischnigg G \& Plagemann A 2005 Duration of breastfeeding and risk of overweight: a meta-analysis. American Journal of Epidemiology 162 397-403.

Harrold JA \& Williams G 2006 Melanocortin-4 receptors, beta-MSH and leptin: key elements in the satiety pathway. Peptides 27 365-371.

Hayashida T, Nakahara K, Mondal MS, Date Y, Nakazato M, Kojima M, Kangawa K \& Murakami N 2002 Ghrelin in neonatal rats: distribution in stomach and its possible role. Journal of Endocrinology 173 239-245.

Kierson JA, Dimatteo DM, Locke RG, Mackley AB \& Spear ML 2006 Ghrelin and cholecystokinin in term and preterm human breast milk. Acta Paediatrica 95 991-995.

Kojima M, Hosoda H, Date Y, Nakazato M, Matsuo H \& Kangawa K 1999 Ghrelin is a growth-hormone-releasing acylated peptide from stomach. Nature 402 656-660.

Korbonits M, Goldstone AP, Gueorguiev M \& Grossman AB 2004 Ghrelin - a hormone with multiple functions. Frontiers in Neuroendocrinology 25 27-68.

Kramer MS 1981 Do breast-feeding and delayed introduction of solid foods protect against subsequent obesity? Journal of Pediatrics 98 883-887.

Kramer MS, Guo T, Platt RW, Vanilovich I, Sevkovskaya Z, Dzikovich I, Michaelsen KF \& Dewey K 2004 Feeding effects on growth during infancy. Journal of Pediatrics 145 600-605.

Lee PC, Kim OK \& Lebenthal E 1982 Effect of early weaning and prolonged nursing on development of the rat pancreas. Pediatric Research 16 470-473.

Mulder H, Lindh AC \& Sundler F 1993 Islet amyloid polypeptide gene expression in the endocrine pancreas of the rat: a combined in situ hybridization and immunocytochemical study. Cell and Tissue Research 274 467-474.

Nishi Y, Hiejima H, Mifune H, Sato T, Kangawa K \& Kojima M 2005 Developmental changes in the pattern of ghrelin's acyl modification and the levels of acyl-modified ghrelins in murine stomach. Endocrinology 146 2709-2715.
Pinto S, Roseberry AG, Liu H, Diano S, Shanabrough M, Cai X, Friedman JM \& Horvath TL 2004 Rapid rewiring of arcuate nucleus feeding circuits by leptin. Science 304 110-115.

Rogers IS, Emmett PM \& Golding J 1997 The growth and nutritional status of the breast-fed infant. Early Human Development 49 S157-S174.

Sundler F, Andersson K \& Mattsson H 1995 Administration of omeprazole to rats for one year produces reciprocal effects on antral gastrin and somatostatin cells and no effect on endocrine cells in the colon. Digestion $\mathbf{5 6}$ 194-198.

Wierup N \& Sundler F 2004 Circulating levels of ghrelin in human fetuses. European Journal of Endocrinology 150405.

Wierup N, Svensson H, Mulder H \& Sundler F 2002 The ghrelin cell: a novel developmentally regulated islet cell in the human pancreas. Regulatory Peptides 107 63-69.

Wierup N, Yang S, McEvilly RJ, Mulder H \& Sundler F 2004 Ghrelin is expressed in a novel endocrine cell type in developing rat islets and inhibits insulin secretion from INS-1 (832/13) cells. Journal of Histochemistry and Cytochemistry $\mathbf{5 2}$ 301-310.

Wortley KE, del Rincon JP, Murray JD, Garcia K, Iida K, Thorner MO \& Sleeman MW 2005 Absence of ghrelin protects against early-onset obesity. Journal of Clinical Investigation 115 3573-3578.

van der Lely AJ, Tschop M, Heiman ML \& Ghigo E 2004 Biological, physiological, pathophysiological, and pharmacological aspects of ghrelin. Endocrine Reviews 25 426-457.

Zigman JM, Nakano Y, Coppari R, Balthasar N, Marcus JN, Lee CE, Jones JE, Deysher AE, Waxman AR, White RD et al. 2005 Mice lacking ghrelin receptors resist the development of diet-induced obesity. Journal of Clinical Investigation 115 3564-3572.

Received in final form 17 November 2006

Accepted 1 December 2006

Made available online as an Accepted Preprint

12 December 2006 